\title{
LEADERSHIP OF THE HEAD MADRASAH IN BUILDING THE SCHOOL CLIMATE IN MADRASAH ALYAH AL- WASHLIYAH 49 PASAR LEMBU, AIR JOMAN DISTRICT, ASAHAN REGENCY
}

\author{
Syafaruddin, Syamsu Nahar, Imran \\ UIN North Sumatra, Medan North Sumatra \\ UIN North Sumatra, Medan North Sumatra \\ Daar Al-Ulum Asahan Institute of Islamic Religion, North Sumatra \\ * Correspondence: syafaruddin@uinsu.ac.id
}

\begin{abstract}
ABSTRACK
This research analyzes the leadership of the madrasa principal in building a school climate, and the example of the madrasa principal in building a school climate in Madrasah Aliyah Al-Washliyah 49 Pasar Lembu, Air Joman District, Asahan Regency.This type of research is a qualitative research approach, through observation, interviews, and document review. This method is used for several reasons, first, adapting this method is easier when dealing with reality. Second, this method presents directly the nature of the relationship between the researcher and the respondent. Third, this method is more sensitive and more adaptable to the many sharpening of joint influences on the patterns of values encountered. The interview targets/respondents in this study included the head of the madrasa, the deputy head of the madrasa, and teachers and all madrasah residents. The formulation of the research problem is 1)How is the leadership type of the madrasa principal in building the school climate in Indonesia? Madrasah Aliyah Al-Washliyah 49 Pasar Lembu, Air Joman District, Asahan Regency; 2)How is the exemplary leadership of the madrasa principal in building a school climate?in Madrasah Aliyah Al-Washliyah 49 Pasar Lembu, Air Joman District, Asahan Regency.The results of the research findings include 1) the type of leadership of the madrasa principal is democratic and fatherly, 2) the exemplary madrasa principal applied includes providing maximum service to all school members.
\end{abstract}

\begin{abstract}
This research analyzes the leadership of the madrasa principal in building a school climate, and the example of the madrasa principal in building a school climate in Madrasah Aliyah Al-Washliyah 49 Pasar Lembu, Air Joman District, Asahan Regency.This type of research is a qualitative research approach, through observation, interviews, and document review. This method is used for several reasons, first, adapting this method is easier when dealing with reality. Second, this method presents directly the nature of the relationship between the researcher and the respondent. Third, this method is more sensitive and more adaptable to the many sharpening of joint influences on the patterns of values encountered. The interview targets/respondents in this study included the head of the madrasa, the deputy head of the madrasa, and teachers and all madrasah residents. The formulation of the research problem is 1)How is the leadership type of the madrasa principal in building the school climate in Indonesia? Madrasah Aliyah Al-Washliyah 49 Pasar Lembu, Air Joman District, Asahan Regency; 2)How is the exemplary leadership of the madrasa principal in building a school climate?in Madrasah Aliyah Al-Washliyah 49 Pasar Lembu, Air Joman District, Asahan Regency.The results of the research findings include 1) the type of leadership of the madrasa principal is democratic and fatherly, 2) the exemplary madrasa principal applied includes providing maximum service to all school members.
\end{abstract}

Keywords: Leadership, principal, school climate. 


\section{A. INTRODUCTION}

The leadership role of the head of Madrasah Aliyah Al-Washliyah 49 Pasar Lembu, Air Joman District, in building an effective school climate requires good cooperation with school personnel and the environment. The school climate which has a strong influence shows that the Islamic community in Indonesia is more likely to enroll their children in school than madrasas, as if madrasas are the number two education after school among ordinary people (Yahya, 2015: 112). Regarding leadership, especially educational leadership, it has become one of the trending topics in various discussions, both in discussion forums and scientific research. The principal as a leader who brings the progress of the educational institution he leads must have certain characteristics and criteria (Qomar, 2008: 288)

The leadership of the head of MAS Al-Washliyah 49 Pasar Lembu, Asahan Regency in building a school climate that is seen by the community as better than the madrasa, here the author finds that the head of the madrasa always provides guidance, direction, training to all madrasa residents, that the head of the madrasa has the type of leadership that always protects all Madrasa residents as servants are not to be served but to serve. This can be seen from the many activities of madrasah/school residents such as scheduled talent development carried out before the learning process begins or in learning activities.

The uniqueness of MAS AlWashliyah when viewed from student activities include Tahfidz Qur'an, speeches, takhtim reading exercises, fardhu kifayah exercises, prayer reading exercises for each student always in the attention of the head of the madrasa before the learning process begins and there is a mutually supportive atmosphere from all elements madrasas, as well as student discipline both in terms of time to enter or leave school but in terms of clothing it also looks neat. Activities that are more direct to the community are also implemented by madrasah principals such as students being directly empowered to fill in the recitation in the male and female perwiridan.

In the leadership of this madrasa head, it is undeniable that there are also teachers who do not carry out their duties and basically as a teacher. It can be seen that there are teachers who are less disciplined such as being late, undisciplined in learning, incomplete teacher administration. And there are also students who are often late to study. However, in leading the school organization, the madrasah principal seems to always be able to build a conducive school climate, as can be seen from the 
way the madrasa principal provides guidance, motivation, advice and training to all madrasah residents in a polite and authoritative manner

\section{B. LITERATURE REVIEW}

\section{Principal Leadership}

Leadership is the process by which individuals influence a group of individuals to achieve a common goal. Process states that leaders influence and are influenced by followers. This emphasizes that leadership is not linear and not a one-way event, but is an interactive event. Leadership can only be truly incarnated if it is displayed by a leader who has the characteristics of leadership. A leader is someone who has the expertise to lead and carry out leadership. $\mathrm{He}$ is able to influence the stance or opinion of a person or group of people without asking the reasons (Danim \& Suparno, 2009: 3).

Leadership is a process of influencing others which is intended to shape behavior according to our will (Harahap, 1996: 233). Meanwhile, according to Syafaruddin (2010: 85) leadership is a natural phenomenon that has been going on for a long time in human behavior as cultured creatures. Leadership can take place in any place and situation. When leadership takes place in the interaction of educators and students, the leadership process is educational leadership.

As an educational leader, the principal is classified as an official leader (formal leader) or a leader as a position (leader status). In his position as an official educational leader, the principal is officially appointed and appointed so that he is responsible for the management of teaching, personnel, students, buildings and yards (facilities and infrastructure), finances, and relations between educational institutions and the community, in addition to his duties in educational supervision. and teaching.

Ngalim Purwanto (2008: 26) defines leadership as a set of abilities and personality traits, including authority, to serve as a means to convince those they lead so that they are willing and able to carry out the tasks assigned to them willingly and enthusiastically., there is an inner joy and a feeling of not being forced.

\section{Madrasa Principal Leadership}

\section{Behavior Perilaku}

There are four different leadership behaviors proposed in Path-Goal Theory by affirming the proposition that managers can facilitate job performance by showing employees how their performance directly affects their acceptance of desired rewards. In other words, leadership behavior is accepted by subordinates as long as it 
quickly or in the future gives satisfaction in their view (Syafaruddin, 2010: 74).

The four leadership behaviors referred to are the results of the Ohio Statae Leadership research as stated by Robbins and Hersey \& Blanchard as stated by Syafaruddin (2010:74-75) in his book "Educational Leadership" as follows:

a. Ordering (directive), namely the leader tells what and when something is done by the employee, there is no participation in decision making.

b. Supportive, i.e. the manager becomes a friend to employees and shows interest in them.

c. Facilitating (facilitative), namely the leader gives suggestions and involves employees in decision making.

d. Achievement-Oriented, where the leader shares contributions about the goals and shows confidence that employees are able to achieve them.

The essence of this theory is that the leader's task is to help members achieve goals and provide direction and support to ensure that these goals are achieved in accordance with all group and organizational goals. So, their behavior is to provide encouragement to the level of job satisfaction and performance achievement by providing guidance, training, support and rewards towards effective performance (Syafaruddin, 2010: 75).

Effective principal leadership can be seen based on the criteria according to Mulyasa (2002: 126), namely as follows:

a. Able to empower teachers to carry out the learning process well, smoothly and productively,

b. able to complete tasks and work in accordance with the time set,

c. Able to establish harmonious relationships with the community so that they can actively involve them in realizing school and educational goals,

d. Successfully apply leadership principles in accordance with the maturity level of teachers and other employees in the school,

e. Work with the management team, and

f. Successfully realize school goals productively in accordance with the provisions that have been set.

Improving the quality of education on a micro basis is largely determined by the operationalization of management at the school level. Education is an important 
issue that must get attention from all parties, given the importance of education in improving the standard of living and the intelligence of the nation's life, it is appropriate for the government to direct special attention to the quality of education and the expansion of higher level learning opportunities for teachers

\section{Building a School Climate}

Climate was originally conceived as the main concept to express strong qualities in organizational life. Litwin and Stringer explain, school climate is defined in various ways by experts as a result of subjective perceptions of the formal system, the informal style of the principal, and other important environmental factors that influence the attitudes, beliefs, values and motivation of individuals who are in the school (Gunbayi, 2003). 2007: 1).

According to Hoy, Smith and Swetland, school climate is understood as a manifestation of school personality that can be evaluated on a continuum from open school to closed school climate. An open school climate is based on respect, trust and honesty, and provides opportunities for teachers, school management and students to engage constructively and cooperatively with one another (Milner, 2008: 158). According to Sorenson and Goldsmith (2008: 30) views the school climate as the collective personality of the school.

School climate is a broad term that refers to the teacher's perception of the school's main work environment; formal organization, informal organization, participant personality, and organizational leadership that influence it. Before explaining the meaning of school climate, several terms that are closely related to school climate will be explained, this is stated with the intention of being able to help understand the concept or meaning of climate in an organization, especially school climate.

School climate is an existing characteristic, which describes the psychological characteristics of a particular school, which distinguishes a school from other schools, affects the behavior of teachers and students and is a psychological feeling that teachers and students have in a particular school (Hadiyanto). , 2004: 153).

School climate based on the description of the opinion above, the notion of school climate is the condition of the work environment that is felt directly or indirectly by teachers in carrying out their duties at school. The indicators for measuring school climate can be seen based on aspects including, among others, the relationship between superiors and 
subordinates, the relationship between fellow members of the organization, responsibilities, fair rewards, work structure, and employee involvement and participation.

\section{Characteristics of a Good School}

\section{Climate}

A conducive school climate and culture is characterized by the creation of a safe, comfortable, and orderly learning environment, so that learning can take place effectively. A conducive school climate and culture is very important so that students feel happy and have a positive attitude towards their school, so that teachers feel valued, and parents and the community feel accepted and involved (Mulyasa, 2015: 90).

There are several indicators of a good school climate and culture according to Mulyasa (2015: 91), which are as follows:

a. School goals that reflect the excellence to be achieved are clearly shown to all school members, set and widely announced in schools.

b. Academic learning objectives in schools are formulated in a measurable way.

c. The school's physical facilities are well maintained, including immediate repair of damaged facilities.

d. The yard and school environment are neat, clean, and comfortable and arranged in such a way that it gives the impression of being beautiful, shady and comfortable.

e. Schools create a sense of belonging so that teachers and students show pride in their school.

f. Teachers are willing to change teaching methods, if better methods are introduced to them.

g. Creating family relationships and togetherness.

h. All teachers and staff are committed to developing a culture of quality in carrying out their daily tasks.

The educational process in schools may cover a wide arena, but priorities and efforts need to be considered. According to Mulyasa (2015: 105), priorities that need to be considered in developing school climate are as follows:

a. School Management Modernization

Schools should not be separated from society. Therefore, in modernizing school management, education implementers should cooperate with other sectors in society that have carried out 
modernization efforts in accordance with technological developments and community needs.

b. Teacher Modernization

Of the various factors that influence school effectiveness, it seems that the teacher factor needs to get first and foremost attention, in addition to the curriculum, because the good or bad of a curriculum ultimately depends on the activities and creativity of the teacher in describing and realizing the curriculum.

c. Learning Modernization

The victims of the education system that is currently experiencing a crisis are actually students, not teachers. On the first day students enter the school they are filled with various questions that must be answered by the teachers. Renewal of learning does not have to be accompanied by the use of all-powerful equipment. In the context of developing teacher education and developing an educational career, it is emphasized the importance of developing new ways of learning that are effective and in accordance with the abilities of each student.

\section{METHOD}

This research was conducted using a qualitative method. This qualitative research uses qualitative methods, namely observation, interviews, or document review. The qualitative method according to Moleong (2010: 9) is used for several reasons, first, adjusting the qualitative method is easier when dealing with multiple realities. Second, this method presents directly the nature of the relationship between the researcher and the respondent. Third, this method is more sensitive and more adaptable to the many sharpening of joint influences on the patterns of values encountered. Qualitative research puts emphasis on meaning, namely the focus of direct study of the problem to be studied. A study was carried out on the practice of Madrasah Principal Leadership in Building School Climate in Madrasah Aliyah Al-Washliyah 49 Pasar Lembu, Air Joman sub-district, Asahan Regency.

\section{DISCUSSION RESULTS}

1. TTypes of Leadership of Madrasah Heads in Building School Climate in Al-Wasliyah Private Madrasah Al-Wasliyah Pasar Lembu, Air Joman District, Asahan Regency 
Based on interviews with several informants, the authors can analyze the type of leadership of the head of Madrasah Aliyah Private Al-Washliyah. The bull market is the head of the madrasa who has a democratic type of leadership, namely inviting all school/madrasah residents to be able to fix the madrasa for the progress of the madrasa in the future. This paternalistic type is also shown by the madrasah principal by being able to be a role model for all teachers such as the madrasa principal being disciplined in attending and returning from the madrasa, being able to speak touching words without hurting the hearts of the school community, being an example for teachers and also students of Madrasah Aliyah Private Al. -Washliyah 49 Pasar Lembu, Asahan Regency.

The success of education in schools and madrasas is largely determined by the success of the principal in managing the school climate, including educators/educational staff, school atmosphere/environment, facilities and infrastructure, regulating student order in schools. The principal is one of the components of education that has an influence in improving and even building a conducive school climate. The school principal is responsible for organizing educational activities, managing school administration and teacher administration in schools, fostering other educators/educational staff, and utilizing and maintaining facilities and infrastructure, as well as school environment order.

The pattern of leadership will be very influential and even determine the progress of the school. Therefore. The role of the principal is a strategic position in achieving school effectiveness. In the hands of the principal, school quality improvement can be achieved, because the principal as a leader has a role to be able to coordinate all personnel in the school to be able to carry out their duties more optimally. The leadership strength of the principal produces various policies and work operations that are guided by a vision that will be used as the basis for achieving school goals. The vision that is carried out consistently must demand climate change that is more oriented towards school effectiveness by being able to accept the atmosphere of differences of opinion between fellow teachers, being able to create a comfortable atmosphere with the same goal.

The climate of Madrasah Aliyah Al Wahsliyah Pasar Lembu Air Joman which was built by the head of the madrasa in order to foster interpersonal communication needs to organize downward communication, namely the head of the madrasa is able to build 
communication that can be accepted by his subordinates sincerely, not by compulsion but on the basis of shared responsibility between leaders and subordinates to be accounted for answer to the parents of students so that children are successful until the end of the education level, if they cannot be accounted for, the trust of parents or the community will be lost which can result in the overall income of the madrasa to be reduced.

The head of madrasah leadership and teachers are used to building a culture and climate that is cool and comfortable for the souls of members by using communication ethics according to the culture of the religious community in accordance with Islamic teachings, where the delivery of information or policies that can be mutually agreed upon in the forum always begins and ends with the expectation God bless.

The upward communication carried out by the head of the Al Wasliyah Private Madrasah Al-Washliyah 49 Air Joman is the leadership that he does, of course, an effort to build a cool climate for the leadership of the al Wasliyah branch and regional leaders because the responsibility for the leadership of the madrasa education institution is directed to the regional leadership of Al Jam'iyah Al- Washliyah district level.
2. Exemplary Leadership of Madrasah Heads in Building School Climate in Al-Wasliyah Private Madrasah Al-Wasliyah Pasar Lembu, Air Joman District, Asahan Regency

Based on the interviews that the authors conducted with several informants, the authors can analyze the leadership examples of the head of MAS AlWashliyah Pasar Lembu, including the head of the madrasah being present before class time starts or the head of the madrasa being present at $07.00 \mathrm{wib}$, the head of the madrasa also seeing or monitoring the classes. class, invites together with teachers and students who are picket to clean the madrasa yard together, give advice to all school residents. The madrasa principal always sets a good example for all school members, in speaking, greeting and the madrasa principal always brings a sense of care and togetherness to all school members without anyone taking sides with one another. Administratively, the principal of the madrasah always shows a good example with the neat administration of the school.

The principal's exemplary is the attitude and behavior of leaders, words and actions that can be imitated and imitated by their subordinates. The head of the madrasa when communicating with madrasa residents always prioritizes 
politeness in acting and speaking because in accordance with his profession in society as a prayer priest and lecturer, he still willing to listen to the advice or opinions of others do not make their own decisions. The principal plays an important role in efforts to improve the quality of teacher work, so that when he speaks he does not hurt the feelings of others and does not speak as he pleases.

A school principal must be able to provide exemplary and quality services to his subordinates. This is very important to do because the principal is the highest leadership in a school or madrasah educational institution. In leading a school principal must be more open to suggestions and constructive criticism. A good principal will be constructive to the current situation, the atmosphere is annoying, worrying, frightening, prejudice, and revenge. A wise principal should be able to be responsive and be able to develop teachers and employees in a better direction. The self-quality of a school principal plays a very important role in improving the quality of the school he leads.

\section{E. CONCLUSION}

Based on the description of the research results above, it can be concluded that the Madrasah Aliyah Al-Washliyah
Asahan with the leadership type of the madrasah principal is very good, this can be seen from the madrasa principal providing an example to all school members in terms of discipline in entering school, the madrasa principal cares about teachers, students and madrasa staff, the madrasa principal often invites teachers to meetings/deliberations in determining a policy for the progress of this madrasa, the madrasa principal is able to become a parent who protects the entire school community and there are no biological children or stepchildren. All are equal in the eyes of this madrasah principal, for those who are disciplined and follow school rules, they are given an award such as an increase in salary, or additional teaching hours, or with public praise during ceremonies, and those who lack discipline are given advice and motivation to do better. Exemplary leadership applied in this madrasa includes providing maximum service to all school members, whether teachers, students or even school/madrasa guards, paying full attention to program evaluations, and giving rewards to teachers who excel and giving warnings to teachers who violate discipline. boost student learning achievement and stimulate teacher teaching passion by participating in national science competence activities and providing teacher training sourced from 
madrasah or district and provincial levels.

Train the entrepreneurial spirit of students and teachers, placing teachers according to their educational expertise in accordance with the teacher's diploma,

\section{BIBLIOGRAPHY}

Danim, Sudarwan \& Suparno. 2009. Management and Transformational Leadership in Principals. Jakarta: Rineka Cipta.

Gunbayi, Ilhan. 2007. School Climate and Teacher's Perceptions on Climate Factors: Research Into Nine Urban High Schools. The Turkish Online Journal of Educational Technology (TOJET).

Hadiyanto. 2004. Looking for a Decentralized Education Management Figure in Indonesia. Jakarta: Rineka Cipta.

Please, Sofyan Syafri. 1996. Contemporary Management. Jakarta: PT RajaGrafindo Persada, 1996.

Milner, Karen \& Khoza, Hariet. 2008. A Comparison of Teachers Stress and School Climate Across Schools with Different Matric Success Rates. South African Journal of Educational.

Moleong, Lexy J. 2010. Qualitative Research Methodology. Bandung: PT. Rosdakarya Youth.

Mulyasa, E. 2002. School-Based Management. Bandung: Rosdakarya Youth, 2002.

Mulyasa, E. 2015. Management and Principal Leadership. Jakarta: Earth Literacy.
Northouse, Peter G. 2013. Leadership Theory and Practice, trans. Ati Cahayani.Jakarta: PT. Gems Puri Media Index.

Purwanto, Ngalim. 2008. Administration and Supervision of Education. Bandung: PT. Rosdakarya Youth.

Qomar, Mujamil. 2008. Management of Islamic Education: A New Strategy for Management of Islamic Educational Institutions. Jakarta: Erlangga.

Sorenson, Ricard D, Goldmith, Lloyd M. 2008. The Principal's Guide to Managing School Personnel, Corwin Press.

Syafaruddin. 2010. Educational Leadership: Accountability of Educational Leaders in the Context of Regional Autonomy. Ciputat: Quantum Teaching Ciputat Press Group.

Yahya, Fata asyrofi. 2015. "Management of Islamic Boarding Schools, Schools, Madrasas; Quality Problems and Quality of Input Process Output." Journal of Tarbawi Vol. VIII No. 1. 
